\title{
Growth Responses of Potato Plantlets Cultured In Vitro under Different Colors Light-Emitting Diodes (LEDs) \\ Genesia Farouk Omar
}

Department of Horticulture, Faculty of Agriculture, Suez Canal University, Ismailia - 41522, Egypt

\author{
Received: $6 / 11 / 2017$
}

\begin{abstract}
This exploration work target was to upgrade the micropropagation of potato cultivars through the utilization of new light sources in the development rooms. The experiment consisted of two potato cultivars (Diamant and agria), and five light sources (white, blue, green and red LEDs; and white fluorescent lights). The explants comprised of nodal segments containing one bud, segregated from plantlets developed in vitro. The experimental design was completely randomized arranged in a 2x5 factorial, with 4 replications. Each experimental unit consisted of a flask with five explants. Three 28-day successive subcultures were done in MS medium and incubated under controlled conditions (temperature $=25+2{ }^{\circ} \mathrm{C}$; photoperiod $=16$ hours; light intensity $=20 \mu \mathrm{mol} \mathrm{m} \mathrm{m}^{-2} \mathrm{~s}^{-1}$ ). Toward the finish of every subculture, plantlet length, number of nodes per plantlet, internode length and plantlet fresh weight were assessed. After the second subculture, differences were found among the two potato cultivars developed in vitro: "Agria" performed better than "Diamant" in most plantlet growth parameters. Different light sources influenced the potato plantlet development: red and green LEDs were the most and least prescribed for plantlet advancement respectively, in view of the after effects of bud number per plantlet, plantlet length. Photosynthetic pigment contents were significantly different under the different light treatments. Chlorophyll a, b and carotenoids were higher in plantlets grown under Red, and less in plantlets under green LED light.
\end{abstract}

Keywords: Solanum tuberosum L., tissue culture, microtuberization, light

\section{INTRODUCTION}

Broccoli (Brassica oleracea var. italica) is a cruciferous crop that is an excellent source of vitamin $\mathrm{C}$, calcium, magnesium, carotenoids, and fiber (Kurilich et al., 1999). Broccoli has received particular attention as the best source of glucosinolates, sulfur-containing compounds, which have been shown to possess health benefits (Fahey et al., 2002). Glucosinolate hydrolysis products could help prevent cancer by enhancing the elimination of carcinogens before they can damage DNA and high intakes of cruciferous vegetables including broccoli have been associated with lower risk of cancer in some epidemiological studies (van Poppel et al., 1999).

Genotypes of plants vary widely in their qualitative and quantitative traits, however, visible plant morphological variation is known to occur at a much lower frequency than at the DNA level (Evans et al., 1984) and as a result, it Potato (Solanum tuberosum L.) is a standout amongst the most critical vegetable harvests in Egypt for local consumption and exportation. The total area devoted to production in the year 2013 in Egypt was 300,662 Fadden, with a total production of around 4,500,000 tons (average 14.96 ton/fed.). Around the world, the potato is the fourth most essential crop, with a yearly production of 325 million tons, (FAO state, 2012). Egypt imports a considerable amount of seed potato for production of table potato, for local consumption and for exportation to Europe and Arab markets (about 250,000 tons annually). Recently for the summer season (2015), Egypt imported about 150,000 tons of seed potatoes from Europe. This huge amount of seeds has a negative influence on the national economy and national hard currency. The alternative available approach for production of certified potato seeds is the only way to solve the problem using micro-propagation in vitro technology. Biotechnology can contribute to the solution of these problems and provide great benefits to potato farmers. The regeneration of plants from the cell and tissue culture represents an essential component of biotechnology and have the potential not only to improve the existing cultivars but also for the generation of novel plants in a comparatively short period of time compared to the conventional breeding method (Abdelaleem, 2015). Virus-free seed potatoes are obtained by means of tissue culture techniques, which represent 17 to $21 \%$ of the total crop costs (Agrianual et al., 2013). Several studies have been made to optimize the micropropagation process, mainly related to culture medium composition (Abdullateef et al., 2009). However, tissue culture environments might be improved by using newly available light sources that might represent lower production costs, especially for seed potato production (Seabrook, 2005; Li et al., 2010).

Recently developed light emission diodes (LEDs) have been pointed out by authors as potential sources of light for in vitro environments cultivation. LEDs are characterized by specific wavelengths, small mass and volume, long useful life, low heating and highly efficient light generation process $(60 \%)$, and do not contain mercury or another hazard element to the environment (Yeh and Chung, 2009). For this reason, interesting research works have been carried out with several plant species grown under LEDs, such as cherry (Muleo and Thomas, 1997), banana (Nhut et al., 2002), strawberry (Rocha et al., 2010), cotton (Li et al., 2010), among others.

This work aimed to optimize the in vitro propagation of two potato cultivars, using different LED light colors in the culture environment. 


\section{MATERIALS AND METHODS}

This work was conducted at the Plant Tissue Culture Lab of the Department of Horticulture, Faculty of Agriculture, Suez Canal University starting in 2016 until 2017. Each experiment repeated twice the time. Laboratory experiments were conducted to optimize the in vitro shoot regeneration induction and development of potato (Solanum tuberosum L.) through studying the effects of genotype as well as the effect of light sources, 1) LED colored tube Phillips, white, blue, green and red, 2) White fluorescent light (provided by white cool florescent lamps; Phillips, Fluotone $40 \mathrm{~W}$ ).

\section{Micropropagation procedures}

Certified seed tubers from two potato genotypes "Diamant" and "Agria" were allowed to grow in the greenhouse in $15 \mathrm{~cm}$ plastic pots filled with vermiculite, one tuber per pot until sprouting took place. Sprouts $(5$ $\mathrm{cm})$ were collected, rinsed with tap water for $10 \mathrm{~min}$. In a laminar air- flow hood, sprout tips were sterilized with $10 \%$ Clorox solution containing $5.25 \%$ sodium hypochlorite for $3 \mathrm{~min}$., then washed three times in sterile distilled $\mathrm{H}_{2} \mathrm{O}$. Shoot meristem tips $(0.5 \mathrm{~mm})$ were isolated under binuclear at $20 \mathrm{x}$ magnification and cultured in $15 \mathrm{~cm}$ test tube (one meristem/test tube) containing $10 \mathrm{ml}$ of Murashige and Skoog (MS) medium (1962) without plant growth regulator (PGR) The medium $\mathrm{pH}$ was adjusted to 5.8 before autoclaving at $110 \mathrm{kPa}$ for $20 \mathrm{~min}$ at $120^{\circ} \mathrm{C}$. Cultured explants were incubated in a controlled environment at $25 \pm 2^{\circ} \mathrm{C}$ and $50 \pm 10 \%$ relative humidity $(\mathrm{RH})$.

Whole plantlet containing about 10 nodes were derived from the culture of each meristem tip. Per each cultivar, meristem-derived plantlets were utilized for further in vitro multiplication using single node cuttings. Nodal segments with single bud were cultured in $250 \mathrm{~mL}$ glass flasks, containing $40 \mathrm{~mL}$ of the same PGR-free MS medium solidified with $7 \mathrm{~g} \mathrm{~L}^{-1}$ Agar, about 5 explants per each flasks The cultures were kept in a growth chamber at constant temperature $\left(25 \pm 2^{\circ} \mathrm{C}\right)$ under illuminations with a photoperiod of $16 \mathrm{~h}$ (Dodds et $a l ., 1992$ referred that a 16-h photoperiod is necessary to maintain vegetative growth of potato plantlets in vitro) and five light sources, as follows: blue LEDs $(18 \mu \mathrm{mol}$ $\left.\mathrm{m}^{-2} \mathrm{~s}^{-1}\right)$, green LEDs, red LEDs $\left(17 \mu \mathrm{mol} \mathrm{m} \mathrm{m}^{-2}\right)$, white led lamps and white fluorescent lamps $\left(30 \mu \mathrm{mol} \mathrm{m} \mathrm{m}^{-2} \mathrm{~s}^{-1}\right.$; control). Under such conditions, three successive 28day long subculture treatments consisted of two potato cv. "Agria" and "Diamond" with five light sources, treatments followed a completely randomized design arranged in a $2 \times 5$ factorial with 4 replications. The unit consisted of a flask with 5 explants. At the end of each subculture, average plantlet length $(\mathrm{mm})$, the number of buds per plantlet, average internodes length $(\mathrm{mm})$ and fresh weight/plantlet $(\mathrm{g})$, were evaluated. The three subculture average values were considered data entries for statistical analysis. At the end of the third subculture, plantlet leaf samples (100 mg of fresh leaf tissue) were collected from the different treatments for analysis (concentration determination) of carotenoids and ( $\mathrm{a}$ and $\mathrm{b}$ ) chlorophylls ( $\mathrm{a}$ and $\mathrm{b}$ ) in $80 \%$ acetone extracts. The pigment quantification was made by spectrophotometry (chlorophyll a at $663 \mathrm{~nm}$; bchlorophyll at $645 \mathrm{~nm}$; and carotenoids at $470 \mathrm{~nm}$ ), according to Lichtenthaler (1987).

\section{General laboratory procedures}

In all in vitro experiments, otherwise mentioned, MS medium basal salts and vitamins $\left(4.2 \mathrm{~g} \mathrm{~L}^{-1}\right.$, Duchefa Biochemie) without PGR was utilized during multiplication stage. Per each liter of MS medium, $30 \mathrm{~g}$ sucrose was added and the $\mathrm{pH}$ was adjusted to 5.7 before the addition of $7.0 \mathrm{~g} \mathrm{~L}^{-1}$ agar for solid medium.

\section{Statistical analysis}

ANOVA was performed using Costat computer program version 6.4 and means separation with LSD test at $5 \%$ level of significance.

\section{RESULTS AND DISCUSSION}

Both of the two potato cultivars "Agria" and "Diamante" showed good in vitro growth under the five studied light sources (white, blue, green, red LEDs, and white fluorescent lamps). In the present research, the analysis of variance showed interactions between potato cultivars and light sources for the variables: average plantlet length average bud number per plantlet and average internode length (Table 1). As tested over two potato genotype, results indicated a significant increase of plantlet height, grown under red LED light condition. Plantlet of cv. "Agria" plantlets showed higher length than cv. "Diamante". The interaction of light and cultivars was significant and the highest number of plantlet length was recorded in cv. Agria $(112 \mathrm{~mm})$ under red led light. About average internode length (mm) "Agria" plantlet showed the longest internodes under all studied light sources, but it did not differ from "Diamant" under blue LEDs $(p<0.05)$. Results also showed an increase of plantlet internode length when grown under red and green LEDs condition. The interaction of light and cultivars was significant and the highest number of internode length was recorded in cv. "Agria" $14.0 \mathrm{~mm}$ under red LED light condition. Poudel et al. (2008) also demonstrated that plant height and internodes length were longer in grape plants cultured under red LEDs.

Higher bud (node) number per plantlet was obtained under red led light condition, where no differences were found among cultivars under all light conditions. On the other hand, green led light was the least responsive light condition since it showed the least bud number per plantlet for both cultivars (Table 1). The same results were reported by Rocha et al. (2015) who showed that green LEDs negatively affected the bud number which decreased in both tested cultivars of potato. The interaction of light and cultivars was significant and the highest number of buds per plantlet was recorded in both "Diamant" (8.41) and "Agria" (8.38) under red led light condition.

About plantlet fresh weight, results showed no significant differences between the two studied cultivars. On the other hand, fluorescent lamps showed highest fresh weight /plantlet followed by red and white LEDs conditions. Concurrent blue and red light 
provided at the beginning of the photoperiod by LEDs resulted in an increase in fresh/dry weight accumulation of potato plantlets in culture (Jao and Fang, 2004).

Such results demonstrated the positive effect of LED light on the in-vitro growth and development of the studied potato cultivars. According to Folta and Maruhnich (2007), red and blue lights induce faster plantlet growth, even faster than white light does, meanwhile green light that is absorbed by phytochromes and cryptochromes, act influencing events that reduce vegetative development.

Furthermore, Wu et al. (2007) reported that red light spectrum emission is near the point of maximum absorption by chlorophylls and phytochromes and it is important for photosynthetic apparatus development and for starch accumulation; and that blue light is relevant for chloroplast development, chlorophyll formation, and stomata opening.

Red LEDs induced longer plantlets in both studied potato cultivars; plantlet length plus internode length are the most important variables to be evaluated for the in vitro propagation process. Kim et al. (2004) and Rocha et al. (2010) had already observed longer plantlets of chrysanthemum and strawberry when grown under red LEDs than under other sources of light. With other potato cultivars, Wilson et al. (1993) obtained longer plantlets under red LEDs, compared to plantlets grown under white fluorescent lamps or even under blue LEDs. Petiole and plantlet length have been associated with red light, which was observed to stimulate and enhance plant species cell lengthening (Wilson et al., 1993). In general, longer plantlets are considered the best in the micropropagation process, because they are easily separated and acclimated, and besides, they contain higher bud number. Villavicencio et al. (2007) observed that potato plantlets of 51 to $70 \mathrm{~mm}$ long presented $91 \%$ survival rate after acclimatization, meanwhile plantlets with less than $30 \mathrm{~mm}$ long showed only $77 \%$ survival rate.

From previous results, it can be concluded that LEDs provide radiant energy for better potato explant and plantlet development in laboratory rooms, and also, they show the advantage of long useful life that may reach 100,000 hours, meanwhile fluorescent lamps present an average useful life of 8,000 hours, and incandescent lamps of 1,000 hours (Rocha et al., 2010). According to these authors, another advantage is the energy saving, since LEDs present high energetic efficiency $(50 \%)$ compared to fluorescent lamps (20\%). This fact directly reduces the plantlet production costs, once the growth room illumination is responsible for $65 \%$ of energy power costs of a tissue culture laboratory (Yeh and Chung, 2009).

The interaction between potato cultivars and light sources for the (chlorophyll a) concentrations were found significant $(\mathrm{p}<0.05)$. Green LEDs induced least (chlorophyll a) concentrations in both studied cultivars. However, no chlorophyll differences were found for 'Agria' and 'Diamant' under red, white, blue LEDs and white fluorescent lamps. Also, green LEDs followed by blue LEDs provided the least (chlorophyll b) concentrations in both cultivars (Table 2). On the other hand, red LEDs followed by white LEDs and fluorescent lamps showed a higher concentration of (chlorophyll b). Higher a- and b-chlorophyll concentrations were obtained under red LED and fluorescent lamps light conditions under which no differences were found among the two studied cultivars under all light conditions. On the other hand, green led light was the least responsive light source once it showed the least a- and b-chlorophyll concentrations for both cultivars (Table 2).

Besides, almost all treatments presented $a: b$ chlorophyll ratio higher than $2(\mathrm{a}: \mathrm{b}>2)$ that is close to the ratio found in plants grown under natural sunlight (3:1) (Streit et al., 2005). According to these authors, chlorophyll "a" is important for the photosynthesis first stage (photochemistry), meanwhile chlorophyll "b" act in the radiant energy capture process and transference to the reaction centers.

Under red LEDs, plantlet leaves elongated but chlorophyll content decreased. It has earlier been reported that red LEDs affect stem elongation, leaf expansion (Hoenecke et al., 1992) and chlorophyll synthesis.

Tripathy and Brown (1995) demonstrated that the decrease in totally fresh and dry weight, and of root weight of plantlets under red LEDs was less than that of plantlets under blue LEDs. This was also observed in our study. This decrease in root weight could be accounted for by the increase in shoot/root ratio under red LEDs as reported earlier (Brown et al., 1995). Our results are also in agreement with Appelgren (1991) for Pelargonium, in which blue light strongly inhibited stem elongation.

There were no significant differences between the two studied cultivars in carotenoids concentrations but significantly differed among light sources (Table 3 ). Highest carotenoids concentrations $\left(0.64\right.$ and $0.63 \mathrm{mg} \mathrm{g}^{-1}$ of fresh tissue) were found in plantlets grown under white fluorescent lamps and red LEDs, respectively, for this variable. Wu et al. (2007) had already observed higher carotenoids accumulation in peas grown under red light. In the present work, the least carotenoids concentrations were obtained under green LEDs, corroborating the results of Rocha et al. (2010), when studying in vitro culture of strawberry. In general, green light is considered a less relevant type of energy for photosynthesis mainly due to its low absorption coefficient (Kim et al., 2004). It is highlighted that chlorophylls and carotenoids synthesized by plants are essential pigments: in the photosynthesis process (light absorption); in preventing plants from photooxidation; in the coloration of plants; and besides, as precursors of vitamins and antioxidants (Wu et al., 2007).

The LED lighting effects on in vitro plantlets were also varied depending on cultivation period as shown in Fig. (1). The third subculture was significantly higher than the second and the first, in both tested cultivars and in most LED treatment color, Also most Averages of growth treatment was higher under red LED light, results in Fig. (1. A and D) showed that plantlet in cultivar Agria showed significant higher than Diamant plantlet cultivar. 
Table (1): Effect of different LED light colors on in vitro explant development of two potatoes cultivars

\begin{tabular}{|c|c|c|c|c|c|c|c|c|c|c|c|c|}
\hline \multirow{3}{*}{ Source of light } & \multicolumn{2}{|c|}{ Cultivar } & \multirow{3}{*}{$\begin{array}{c}\text { Mean of } \\
\text { Sources } \\
\text { light }\end{array}$} & \multicolumn{2}{|c|}{ Cultivar } & \multirow{3}{*}{$\begin{array}{l}\text { Mean } \\
\text { Sources } \\
\text { of light }\end{array}$} & \multicolumn{2}{|c|}{ Cultivar } & \multirow{3}{*}{$\begin{array}{c}\text { Mean } \\
\text { Sources of } \\
\text { light }\end{array}$} & \multicolumn{2}{|c|}{ Cultivar } & \multirow{3}{*}{$\begin{array}{c}\text { Mean } \\
\text { Sources } \\
\text { of light }\end{array}$} \\
\hline & Diamant & Agria & & Diamant & Agria & & Diamant & Agria & & Diamant & Agria & \\
\hline & \multicolumn{2}{|c|}{$\begin{array}{c}\text { average plantlet } \\
\text { length }(\mathrm{mm})\end{array}$} & & \multicolumn{2}{|c|}{$\begin{array}{l}\text { Average bud number } \\
\text { per plantlet }\end{array}$} & & \multicolumn{2}{|c|}{$\begin{array}{l}\text { average internode } \\
\text { length }(\mathrm{mm})\end{array}$} & & \multicolumn{2}{|c|}{ Plantlet FW. } & \\
\hline Blue LED & $40.3 \mathrm{~d}$ & $47.0 \mathrm{~d}$ & $43.63 \mathrm{C}$ & $6.10 \mathrm{e}$ & $6.48 \mathrm{de}$ & $6.29 \mathrm{D}$ & $5.78 \mathrm{~d}$ & $7.18 \mathrm{~d}$ & $6.48 \mathrm{D}$ & $84.1 \mathrm{~d}$ & $83.5 \mathrm{~d}$ & $83.8 \mathrm{D}$ \\
\hline Green LED & $74.3 \mathrm{c}$ & $77.5 \mathrm{c}$ & $75.88 \mathrm{~B}$ & $4.43 \mathrm{~g}$ & $5.17 f$ & $4.80 \mathrm{E}$ & $10.75 b$ & $12.75 \mathrm{ab}$ & $12.00 \mathrm{~A}$ & $140.5 b c$ & $122.5 \mathrm{~cd}$ & $131.5 \mathrm{C}$ \\
\hline Red LED & $92.8 \mathrm{~b}$ & $112.0 \mathrm{a}$ & $102.38 \mathrm{~A}$ & $8.41 \mathrm{a}$ & $8.38 \mathrm{a}$ & $8.39 \mathrm{~A}$ & $11.25 b$ & $14.00 \mathrm{a}$ & $12.38 \mathrm{~A}$ & $169.8 \mathrm{abc}$ & $178.8 \mathrm{ab}$ & 174.3B \\
\hline White LED & $71.3 \mathrm{c}$ & $80.3 \mathrm{c}$ & $75.75 \mathrm{~B}$ & $6.53 \mathrm{de}$ & $7.02 \mathrm{~cd}$ & $6.78 \mathrm{C}$ & $8.23 \mathrm{~cd}$ & $11.83 \mathrm{ab}$ & $10.03 \mathrm{~B}$ & $173.5 \mathrm{abc}$ & $143.5 b c$ & $158.5 \mathrm{~B}$ \\
\hline White fluorescent & $68.8 \mathrm{c}$ & $74.8 \mathrm{c}$ & $71.75 \mathrm{~B}$ & $8.05 \mathrm{ab}$ & $7.58 \mathrm{bc}$ & $7.81 \mathrm{~B}$ & $6.53 \mathrm{~d}$ & $10.05 b c$ & $8.29 \mathrm{C}$ & $204.5 \mathrm{a}$ & $204 a$ & $204.3 \mathrm{~A}$ \\
\hline Mean cv. & $69.45 \mathrm{~B}$ & $78.3 \mathrm{~A}$ & & $6.70 \mathrm{~A}$ & $6.92 \mathrm{~A}$ & & $8.51 \mathrm{~B}$ & $11.16 \mathrm{~A}$ & & $154.5 \mathrm{a}$ & $146.5 \mathrm{a}$ & \\
\hline
\end{tabular}

**Means with the same letters for main effects and interactions are not significantly different according to LSD test at 5\%

Table (2): Chlorophyll ( $a$ and $b$ ) concentrations $\left(\mathrm{mg} \mathrm{g}^{-1}\right)$ in plantlets of two potato cultivars, grown in vitro under different LED light colors

\begin{tabular}{|c|c|c|c|c|c|c|}
\hline \multirow{3}{*}{ Source of light } & \multicolumn{2}{|c|}{ Cultivar } & \multirow{3}{*}{$\begin{array}{c}\text { Mean of } \\
\text { Sources light }\end{array}$} & \multicolumn{2}{|c|}{ Cultivar } & \multirow{3}{*}{$\begin{array}{c}\text { Mean of } \\
\text { Sources light }\end{array}$} \\
\hline & Diamant & Agria & & Diamant & Agria & \\
\hline & \multicolumn{2}{|c|}{ Chlorophyll a (mg g $\left.{ }^{-1}\right)$} & & \multicolumn{2}{|c|}{ Chlorophyll b (mg g $\left.\mathrm{g}^{-1}\right)$} & \\
\hline Blue LED & $1.02 \mathrm{~b}$ & $1.06 \mathrm{a}$ & 1.04B & $0.44 \mathrm{c}$ & $0.44 \mathrm{~b}$ & $0.44 \mathrm{C}$ \\
\hline Green LED & $0.45 c$ & $0.41 \mathrm{~b}$ & $0.43 \mathrm{C}$ & $0.19 \mathrm{~d}$ & $0.27 \mathrm{c}$ & $0.23 \mathrm{D}$ \\
\hline White LED & $1.19 \mathrm{ab}$ & $1.13 \mathrm{a}$ & $1.16 \mathrm{~B}$ & $0.54 b c$ & $0.56 \mathrm{ab}$ & $0.55 \mathrm{~B}$ \\
\hline White fluorescent & $1.39 \mathrm{a}$ & $1.40 \mathrm{a}$ & $1.39 \mathrm{~A}$ & $0.63 b$ & $0.64 \mathrm{a}$ & $0.64 \mathrm{~A}$ \\
\hline Mean cv. & $1.09 \mathrm{~A}$ & $1.08 \mathrm{~A}$ & & $0.51 \mathrm{~A}$ & $0.50 \mathrm{~A}$ & \\
\hline
\end{tabular}

**Means with the same letters for main effects and interactions are not significantly different according to LSD test at 5\% 
Table (3): Effect of different LED light colors on Carotenoids concentrations ( $\left.\mathrm{mg} \mathrm{g}^{-1}\right)$ in plantlets of two potato Cultivars

\begin{tabular}{|c|c|c|c|}
\hline \multirow{3}{*}{ Source of light } & \multicolumn{2}{|c|}{ Cultivar } & \multirow{3}{*}{$\begin{array}{c}\text { Mean } \\
\text { Sources of light }\end{array}$} \\
\hline & Diamant & Agria & \\
\hline & \multicolumn{2}{|c|}{ Carotenoids $\left(\mathrm{mg} \mathrm{g}^{-1}\right)$} & \\
\hline Blue LED & $0.54 \mathrm{ab}$ & $0.49 \mathrm{~b}$ & $0.51 \mathrm{~B}$ \\
\hline Green LED & $0.19 \mathrm{c}$ & $0.22 \mathrm{c}$ & $0.21 \mathrm{C}$ \\
\hline Red LED & $0.63 \mathrm{a}$ & $0.64 \mathrm{a}$ & $0.63 \mathrm{~A}$ \\
\hline White LED & $0.47 \mathrm{~b}$ & $0.49 \mathrm{~b}$ & $0.48 \mathrm{~B}$ \\
\hline White fluorescent & $0.62 \mathrm{a}$ & $0.65 \mathrm{a}$ & $0.64 \mathrm{~A}$ \\
\hline Mean cv. & $0.49 \mathrm{~A}$ & $0.50 \mathrm{~A}$ & \\
\hline
\end{tabular}

**Means with the same letters for main effects and interactions are not significantly different according to LSD test at $5 \%$

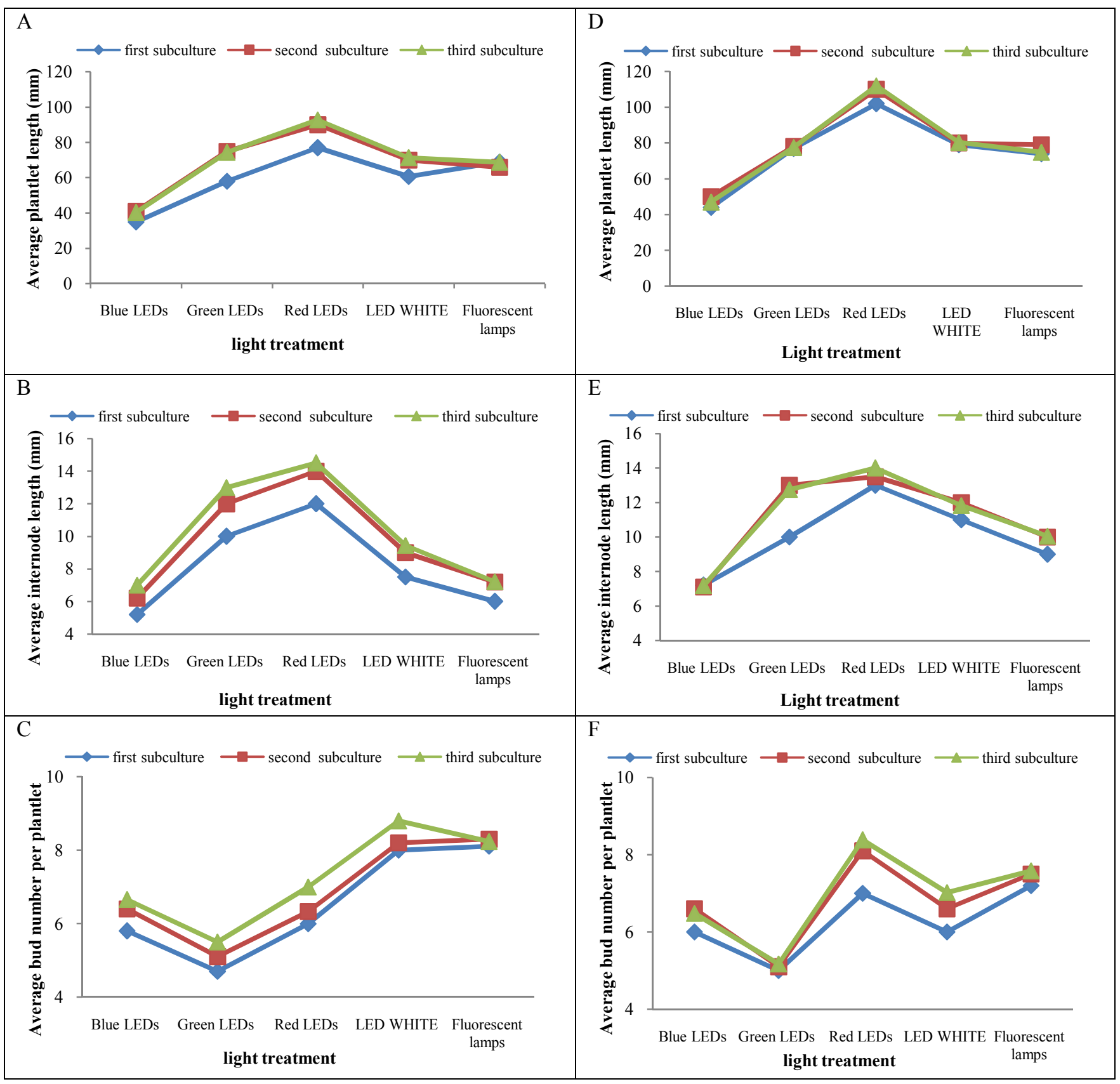

Figure (1): In vitro growth of potato cultivars under different LED lighting sources after first, second and third sub-culture. The Figures (A), (B) and (C) show the growth of cultivar "Diamant" and (D), (E) and (F) show cultivar "Agria" 


\section{CONCLUSION}

Light emitting diode (LED) has been proposed as a potential alternative light source for growth and development of in vitro potato plant growth. Led light is promising tools to decrease high costs in plant production by tissue culture. A genetic effect of potato cultivar in the process of in vitro propagation was evident since Agria showed higher growth than Diamont.

LEDs can be used as source of light in substitution to the white fluorescent lamps in tissueculture growth rooms for in vitro potato propagation. The light source of growth rooms influenced the potato explants development in vitro: red LEDs were the most and green LEDs the least recommended for plantlet vegetative development.

\section{REFERENCES}

Abdelaleem, K. G. (2015). In vitro Organogenesis of (Solanum tuberosum L.) plant cultivar alpha through tuber segment explants callus. Int. J. Curr. Microbiol. App. Sci., 4(2): 267-276.

Abdullateef, S., I. Pinker and M. Bohme (2009). Potato micropropagation using advanced biotechnology: Effect of liquid media on potato shoot quality. Acta Horticultuare, The Hague, 850: 135-142.

Agrianual-Anuário da agricultura brasileira (2013). Batata. São Paulo: Agra FNP, p. 181-188.

Appelgren, M. (1991). Effects of light quality in stem elongation of Pelargonium in vitro. Sci. Hort., 45: 345-351.

Brown, C. S., A. C. Schuerger and J. C. Sagar (1995). Growth and photo- morphogenesis of pepper plants under red light-emitting diodes with supplemental blue or far-red light. J. Am. Soc. Hort. Sci., 120: 808-813.

Dodds, J. H., D. Silva-Rodriguez and P. Tovar (1992). Micropropagation of potato. In: YPS Bajaj (ed), Biotechnology in Agriculture and Forestry 19-High-tech and Micropropagation HI. Springer-Verlag, Berlin, pp 92-106.

FAO (2012). Statistical database FAOSTAT. Available on line at: http//Faostate.Fao.Org/site 567/default. Aspxx\#ancor.

Folta, K. M.; S. A. Muruhnich (2007). Green light: a signal to slow down or stop. Journal of Experimental Botany, London, 58: 30993111.

Hoenecke, M. E., R. J. Bula and T. W. Tibbitts (1992). Importance of 'blue' photon levels for lettuce seedlings grow under red light-emitting diodes. HortScience, 27: 427-430.

Jao, R.C. and W. Fang (2004). Growth of potato plantlets in vitro is different when provided concurrent versus alternating red and blue light photoperiods. HortScience, 39(2): 380382.

Kim, S. J., E. J. Hahn, J. W. Hoe and K. Y. Paek (2004). Effects of LEDs on net photosynthetic rate, growth and leaf stomata of chrysanthemum plantlets in vitro. Scientia Horticulturae, Amsterdam, 110: 143-151.

Li, H., Z. Xu and C. Tang (2010). Effect of lightemitting diodes on growth and morphogenesis of upland cotton (Gossypium hirsutum L.) plantlets in vitro. Plant Cell, Tissue and Organ Culture, The Hague, 103: 155-163.

Lichtenthaler, H. K. (1987). Chlorophylls and carotenoids: the pigments of photosynthetic biomembranes. In: Douce R; Packer L (eds). Methods in enzymology. Washington: Academic Press, p. 350-382.

Muleo, R. and B. Thomas (1997). Effects of light quality on shoot proliferation of Prunus cerasifera in vitro are the result of differential effects on bud induction and apical dominance. Journal of Horticultural Science, London, 72: 483-492.

Murashige, T. and F. Skoog (1962). A revised medium for rapid growth and bio-assays with tobacco tissue cultures. Physiologia Plantarum, 15(3): 473-497.

Nhut, D. T., L. T. A. Hong, H. Watanable, M. Goi and M. Tanaka (2002). Growth of banana plantlets cultured in vitro under red and blue lightemitting diodes (LED) irradiation source. Acta Horticulturae, The Hague, 575: 117124.

Poudel, P. R., I. Kataoka and R. Mochioka (2008). Effect of red- and blue-light-emitting diodes on growth and morphogenesis of grapes. Plant Cell Tiss. Org., 92(2): 147-153.

Rocha, P. S. G., R. P. Oliveira, W. B. Scivitaro and U. L. Santos (2010). Diodos emissores de luz e concentrações de BAP na multiplicação in vitro de morangueiro. Ciência Rural, Santa Maria, 40: 1922-1928.

Rocha, P. S. G., R. P. Oliveira and W. B. Scivittaro (2015). New light sources for in-vitro potato micropropagation. Biosci. J., Uberlândia, 31(5): 1312-1318.

Seabrook, J. E. A. (2005). Light effects on the growth and morphogenesis of potato (Solanum tuberosum) in vitro: a review. American Journal of Potato Research, New York, 82: 353-367.

Streit, N. M., L. P. Canterle, M. W. Canto and L. H. H. Hecktheuer (2005). As clorofilas. Ciência Rural, Santa Maria, 35: 748-755.

Tripathy, B. C. and C. S. Brown (1995). Root-shoot interaction in the greening of wheat seedlings grown under red light. Plant Physiol., 107: 407-411.

Villavicencio, E. G., A. J. V. Gámez, M. A. Arellano, J. H. J. Almeida Fernández (2007). Micropropagation in four potato genotypes and selection on vitro plants size as a survial ex vitro establishment. Acta Horticulturae, The Hague, n. 748, p. 223-227, 2007. 
Wilson, D. A., R. C. Weigel, R. M. Wheeler and J. C. Sager (1993). Light spectral quality effects on the growth of potato (Solanum tuberosum L.) nodal cutting in vitro. In Vitro Cellular and Developmental Biology, Berlin, 29: 5-8.

Wu, M. C., C. Y. Hou, C. M. Jiang, Y. T. Wang and C. Y. A. Wang (2007). A novel approach of LED light radiation improves the antioxidant activity of pea seedlings. Food Chemistry, Cambridge, 101: 1753-1758.

Yeh, N. and J. P. Chung (2009). High-brightness LEDs: energy efficient lighting sources and their potential indoor plant cultivation. Renewable and Sustainable Energy Reviews, Taiwan, 13: 2175-2180.

\title{
استجابة النمو لنبتيات البطاطس المنزرعة معملياً لألوان مختلقه من ضوء مصابيح
}

\author{
جينيسيا فاروق عبد العزيز عمر

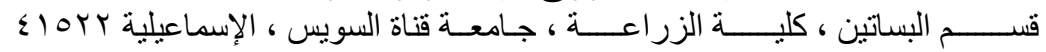

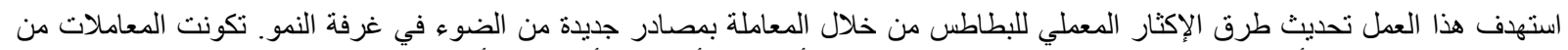

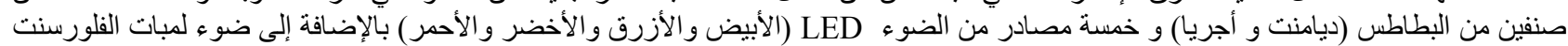

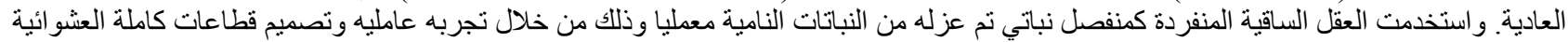

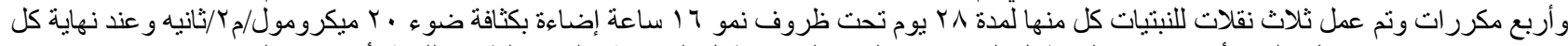

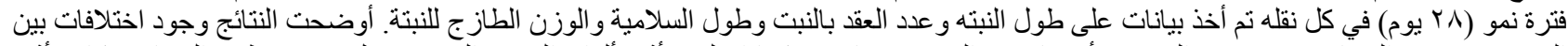

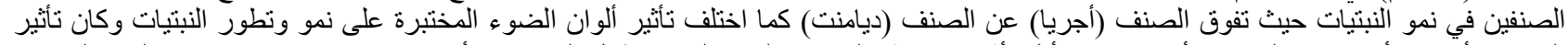

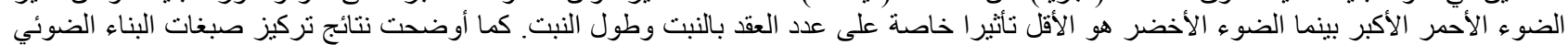

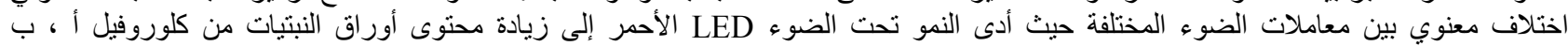
و الكاروتينات بينما كانت تركيز ات هذه المواد الأقل تحت ظروف الند النمو في الضوء LED الأخضر. 